\title{
七ートシウムーアクリロニトリルー黒鉛三元層間化合物の合成
}

\author{
吉岡隆幸**, 松本里香*, 高橋洋一*, 阿久沢 昇 ${ }^{\star \star \star ~}$
}

(平成12年9月28日受理, 平成12年11月14日採択)

\section{Synthesis of Ternary Cesium-Acrylonitrile-Graphite Intercalation Compound}

\author{
Takayuki Yoshioka**, Rika Matsumoto*, Yoichi Takahashi* and Noboru Akuzawa***
}

\begin{abstract}
The sorption isotherm and the desorption behavior of acrylonitrile (AN) into $\mathrm{CsC}_{24}$ at $300 \mathrm{~K}$ were investigated. The maximum amounts of acrylonitrile sorbed, AN/Cs, was $1.2 \sim 1.4$, and the sorption-desorption process was irreversible.

The stage structure of the resulting ternary compound, after exposure to air, was determined by X-ray diffraction and Raman shift measurements and was confirmed to be mainly ternary stage- 2 structure with $I c=1.00 \mathrm{~nm}$. The change of XRD patterns of the compound with time was not so significant, while the electrical conductivity decreased rapidly. The heat-treatment of the sample gave little effect for the stabilization of the ternary compound.
\end{abstract}

KEYWORDS : Intercalation, Alkali metal, Acrylonitrile

\section{1. 緒 言}

黑鉛層間化合物 (GIC) は軽量でかつ高い電気伝導率を有 する材料として注目されているが, 黒鉛にアルカリ金属をイ ンターカレートした層間化合物 (AM-GIC) は一般に大気中 で不安定である。

一方, AM-GIC (特にステージ2以上の高ステージ) は, その 空隙にさまざまな有機分子を取り込むことができることがよ く知られており1)-3)，われわれはCsC $\mathrm{C}_{24}$ にエチレンを吸収させ た系では高い電気伝導率を維持しながら大気中で比較的安定 であることを見出している4-7)。これは, 層間のナノスペース においてエチレンが二次的反応 (オリゴメリゼーション)を 起こしCsの拡散, 層間よりの放出を抑制するためと考えられ る。有機分子の重合度が増せば, さらにGICの大気中安定性 が改善されるものと推察される。

本研究では, 二元系ステージ2のCsC 24 に重合性の高いアクリ ロニトリル (以後ANと表記) を気体接触法により反応させ, そ の吸収挙動を調べるとともに, XRDおよびラマン分光測定, 電 気伝導率の測定を行い, 合成された三元系GICの評価を行った。

\section{2. 実 験}

\section{1 試 料}

ホストの黒鉛にはグラフォイル (UCAR社製; GTA級) を
用いた。サイズ $0.4 \times 50 \times 3 \sim 5\left(\mathrm{~mm}^{3}\right)$ の短冊状に切り出し, 真空中, 約 $1173 \mathrm{~K} て ゙$ 熱処理を施して揮発成分を除去した。Cs は添川理化学(侏)製（純度 $99.95 \%), \mathrm{CsC}_{24}$ に吸収させるANは 東京化成工業製（純度99\%) を用い, それぞれ蒸留精製して実 験に供した。

上記のグラフォイル, $\mathrm{Cs}$ を $\mathrm{CsC}_{24}$ の組成比になるよう秤量, 採取し,パイレックスガラス管中でTwo-bulb法により反㐫さ せ, その後約 $700 \mathrm{~K} て ゙$ 均質化熱処理して, 青色の光沢を持つ二 元系ステージ2GICを合成した。合成した試料は2組（それぞ れA，Bと表記する) であり，その組成は，反応に用いたガラス 管に付着し残留したCs量を補正すると, 試料 $\mathrm{A}$ は $\mathrm{CsC}_{27.0}$, 試料 $\mathrm{B}$ はCsC 24.2 であった。

\subsection{ANの吸収実験}

合成した $\mathrm{CsC}_{24}$ 試料へのANの吸収は, 気体接触法によりパイ レックスガラス管中で行った。 $\mathrm{CsC}_{24}$ 試料部の温度を $300 \mathrm{~K} に$, AN部およびガス溜め部などを室温 (<300K) に保ったのち, AN蒸気を系内およびガス溜めに導入し，この時のANの蒸気压 を測定する。反応開始後の圧力の時間变化および気温を測定 し, AN吸収量を系内の容積と反応前後の圧力变化から気体の 状態方程式を用いて算出した。ANの圧力の時間変化が認めら れなくなった (平衡蒸気圧に達した) 後, 系内にAN蒸気を補充 し, 次の平衡圧までのAN吸収量を同様にして測定する。 吸収実験終了後, 装置内を隇圧として試料からのAN脱着実

* 中央大学理工学部応用化学科：干112-8551 東京都文京区春日1-13-27

* Department of Applied Chemistry, Chuo University : 1-13-27, Kasuga, Bunkyo-ku, Tokyo 112-8551, Japan

** 新潟大学大学院自然科学研究科材料生産開発科学専攻: $7950-2181$ 新潟市五十嵐二の町8050

** Graduate School of Science and Technology, Niigata University : 8050, 2-nocho, Ikarashi, Niigata 950-2181, Japan

*** 東京工業高等専門学校物質工学科：干193-8610 東京都八王子市椚田町1220-2

*** Department of Chemical Science and Engineering, Tokyo National College of Technology : 1220-2, Kunugida, Hachioji, Tokyo 193-8610, Japan 
験を行い,その後10-3Torrの真空下で放出ガスのないことを 確かめてから試料を大気下に取り出した。

\section{3 三元系GICのキャラクタリゼーション}

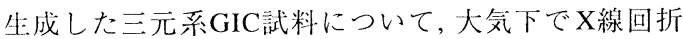
(XRD) 测定を行うとともに, その経時变化を测定した。XRD 测走は, $\mathrm{CuK} \alpha$ 線, $0.033^{\circ} \mathrm{s}^{-1}$ の走査速度で, $2 \theta$ が $5 \sim 80^{\circ}$ の範 闻を走査した。

また，四端子法により，293Kでの試料の電気伝導率および その経時変化を測定した。

\section{3. 結果と考察}

\section{1 吸収挙動と試料の構造}

Fig.1に試料A，Bに対するAN吸収アイソサームを示す。吸 収開始からある一点の圧力下で平衡に達するまでに三日から 一週間ほどを要し,一つの試料のアイソサームを完成するの に一ヶ月強の期間を要した。ANの導入圧力が室温における 純ANの平衡蒸気圧（約 $13 \mathrm{kPa}$ ) 以下であり, 試料部との圧力 勾配が小さいこともあるが, Cs-エチレン系と比較すると反応 は非常に遅い。三元系と平衡のANの圧力が約 $11 \mathrm{kPa}$ に達し たときのANの吸収量 (最大吸収量) は試料A,Bについてそれ ぞれAN/Cs=1.2および1.4となった。また, 脱着は確認され ず反応は不可逆であった。これより, 大気下に取り出したと きの三元系試料A，Bの組成は,それぞれC $\mathrm{Cs}_{27.0}(\mathrm{AN})_{1.2}$ および $\mathrm{CsC}_{24.2}(\mathrm{AN})_{1.4}$ である。

Fig.2にこのようにして合成した三元系試料Bについての XRDパターンを示す。大気下に取り出してから10分後の測 定では繰り返し距離 $I c=1.00 \mathrm{~nm}$ (後述のように, 三元系ステ 一ジ2構造と推定される。T2 と表記) と $I c=0.68 \mathrm{~nm}$ (三元系 ステージ1を示すと思われるピーク，T1）が観察された。また， $I c=0.96 \mathrm{~nm}$ に相当するピークも観察されたが, これは二元系 ステージ2の文献值 $\left(0.94 \mathrm{~nm}^{8)}\right)$ よりやや大きく, 多分部分的 にANが挿入された構造と思われる。なお,このピークは一日 後には消失した。

ステージ2構造を想定したIc=1.00nmについては, Fig.2に

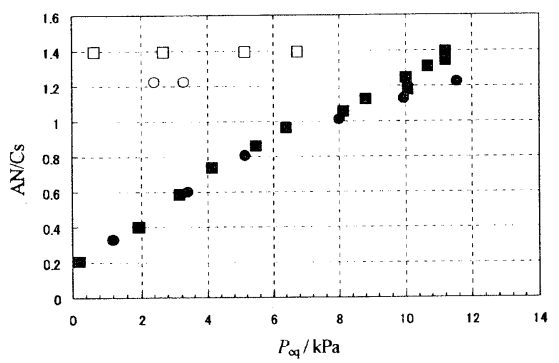

Fig.1 Sorption isotherms of $\mathrm{CsC}_{27.0}$ (sample $\mathrm{A}$ ) and $\mathrm{CsC}_{24.2}$ (sample B) -acrylonitrile system at $300 \mathrm{~K}$. , sorption ; $\bigcirc$, desorption of sample A : sorption ; $\square$, desorption of sample B.
見られるように $(003)$ ，(006）の回折ピークが観測されるの みで, Cs一エチレン一黒鉛三元系の場合5)のように, (001), (002) が明暸に観察されているわけではない。また，(003） 主ピークはホスト黒鉛 $(I c=0.674 \mathrm{~nm})$ の (002) 回折ピーク に近いのでここの元系試料がたしかにステージ2構造であ ることを確かめる必要がある。このため,この試料を大気下 で試料容器中に保存したものを, その後 (18ヶ月後)にラマン 分光により検討した。その結果は, その他の三元系試料の結 果とともに別途報告9)したが, 大気下に長期間放置した後で も, Bounding layerに対応する $(1605 \pm 1) \mathrm{cm}^{-1}$ のピークがか なりの強度で認められ，ステージ2構造の存在をはっきり支 持するものと考えられる。

\section{2 経時変化}

Fig.2に三元系試料BのXRDパターンの経時変化を, Fig.3 に試料Aについての電気伝導率の経時変化を示す。XRDパ夕 ーンは特にT2ピークに関しては長期間にわたって変化が少 なくこの構造は大気下で安定のように思われる。一方, 電気 伝導率の経時変化は,一ヶ月の間に急激に优が減少して約 $3 \times$ $10^{3} \mathrm{Scm}^{-1}$ に収束し, Cs－エチレン系のように長期間高電気伝 導率を維持することはできなかった。

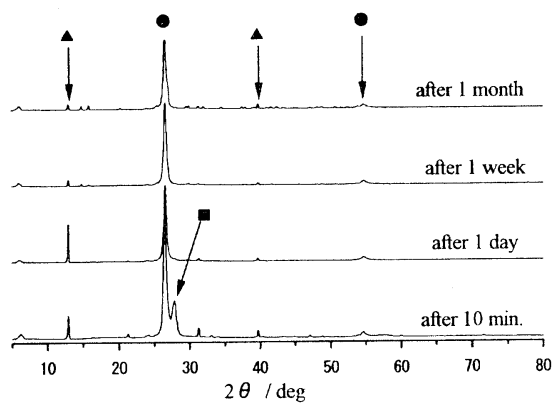

Fig.2 Time dependence of $\mathrm{X}$-ray diffractogram for $\mathrm{CsC}_{24.2}$ $(\mathrm{AN})_{1.4}($ sample B $) . \mathbf{O}, I c=1.00 \mathrm{~nm}(\mathrm{~T} 2) ; \mathbf{A}, I c=$ $0.68 \mathrm{~nm}(\mathrm{~T} 1) ; \mathrm{B}, I c=0.96 \mathrm{~nm}$.

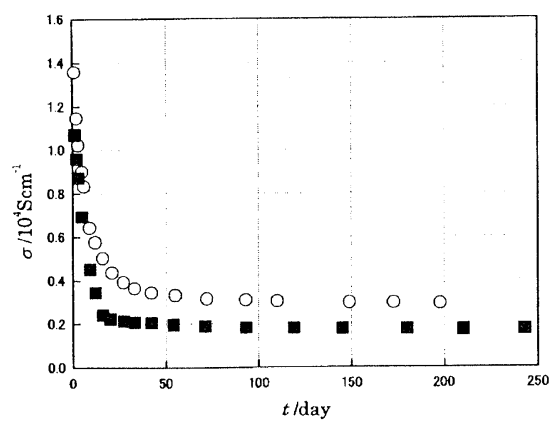

Fig.3 Time dependence of electrical conductivity at $293 \mathrm{~K}$. $\bigcirc, \mathrm{CsC}_{27.0}(\mathrm{AN})_{1.2}$ (sample A) ;, $\mathrm{CsC}_{24.2}(\mathrm{AN})_{1.4}$ (sample B after heat treatment). 
以上のように, XRDパターン的には萝しい変化はふささない が, 電気伝導率は急激に低下することから,この二元系GICで は層間におけるANの重合はあまり進行していないか, 重合は しても蟹间のCsを取り囲むだけのネットワークが発達してい ないものと考えられる。

なお, 高温下でのANの重合促進効果を期街して, 三元系試 料Bについて $323 \mathrm{~K} て ゙ 150$ 時間, 真空下で熱処理をしたのちに 同様にXRDおよび電気伝導率の経時变化の測定を行ったが, XRDの結果は熱処理前の試料とほとんど変わらなかったの に対して, 電気伝導率は, Fig.3に示すように熱処理をしなか った試料Aと同様に時間の経過とともに急激に低下し, 期待 した安定化効果はまったく見られなかった。

\section{4. 結 言}

二元系ステージ20CsC 24 に300Kでアクリロニトリル (AN) を吸収させ三元系GIC $\mathrm{CsC}_{24}(\mathrm{AN})_{1.2 \sim 1.4}$ を合成した。生成し た三元系化合物は真空下でもANの脱着は見られず, 反応は不 可逆であった。XRD, ラマン分光の測定結果よりこの三元系 は, 主として $I c=1.00 \mathrm{~nm}$ のステージ2構造をとるものと考えら れた。XRDパターンの経時变化はわずかであるが, 電気伝導 率は時間の経過とともに急激に低下した。323Kでの熱処理 を施した試料も時間の経過とともに電気伝導率は急激に低下 し, Csーエチレン系のような長期間安定な三元系GICを得る ことはできなかった。

\section{謝 辞}

本研究の遂行に協力頂いた中央大学:卒業研究学生奥村聡史 君に謝意を表する。また，本研究は，日本学術振興会木来開拓 学術研究推進事業の研究プロジェクト「炭素材料中への機能 性ナノおよびミクロスペースの創製」(JSPS-RFTF96R11701) の一環として行われたものである。

\section{文 献}

1) K. Watanabe, T. Kondow, M. Soma, T. Onishi and K. Tamaru, Proc. Roy. Soc. Lond. A 333 (1973) 51-67.

2) L. Bonnetain, P. Touzain and A. Hamwi, Mat. Sci. Eng. 31 (1977) 45-51.

3) M. Goldmann, H. Pilliere and F. Beguin, Syn. Met. 34 (1989) 59-65.

4) Y. Takahashi, K. Oi, T. Terai and N. Akuzawa, Carbon 29 (1991) 283-285.

5) H. Pilliere, Y. Takahashi, T. Yoneoka, T. Otosaka and N. Akuzawa, Syn. Met. 59 (1993) 191-199.

6) N. Akuzawa, S. Kondou, Y. Kaburagi, Y. Hishiyama and Y. Takahashi, Carbon 31 (1993) 963-968.

7) Y. Takahashi, TANSO 1993 [No.160] 301-311 [in Japanese].

8) M. S. Dresselhaus and G. Dresselhaus, Adv. in Phys. 30 (1981) 175 .

9) R. Matsumoto, Y. Takahashi and N. Akuzawa, Mol. Cryst. and Liq. Cryst. 340 (2000) 43-48. 